\title{
ARTICLE \\ Genetic diversity within local and introduced cultivars of wheat (Triticum aestivum L.) grown under Mediterranean en- vironment as revealed by AFLP markers
}

\author{
Arabi M.I.E., Shoaib A., Al-Shehadah E., Jawhar M.* \\ Department of Molecular Biology and Biotechnology, Atomic Energy Commission of Syria, Damascus, Syria
}

\begin{abstract}
Information on genetic diversity among cultivars is critical in wheat improvement. In this work, heterogeneity within local and introduced cultivars of bread wheat grown in Syria was investigated using amplified fragment length polymorphism (AFLP) markers. The eight primer pairs were used to detect 177 polymorphic bands among the 21 cultivars resulting in an average of 22.13 (57.3\%) polymorphic loci per primer pair. Major allelic frequency ranged from 0.50 to 0.75 with a mean 0.64 , and estimated gene diversity was 0.45 . Values of average polymorphic information content (PIC) for these markers were estimated to be 0.34 . This low value might be attributed to the rigorous selection pressure aimed at cultivar purity and associated breeding practices. Dissimilarity values ranged from 0.32 to 0.66 with an average of 0.54 , indicating that such techniques sample distinct genome regions. Three major subgroups of wheat cultivars were identified using the unweighted pair-group method with arithmetic means analysis (UPGMA), with all local cultivars falling into one cluster, which was confirmed by a principal component analysis (PCA). The narrow genetic diversity observed among Syrian wheat cultivars suggests the need of broadening the genetic base of wheat breeding materials, including local landraces.

Acta Biol Szeged 63(1):25-30 (2019)
\end{abstract}

\section{KEY WORDS}

AFLP markers bread wheat genetic diversity germplasm $\mathrm{PIC}$

\author{
ARTICLE INFORMATION \\ Submitted \\ 16 May 2019. \\ Accepted \\ 10 July 2019 \\ *Corresponding author \\ E-mail: ascientific2@aec.org.sy
}

\section{Introduction}

Bread wheat (Triticum aestivum L.) is one of the most important cereal crops in the world. Simultaneously, the demand for food is increasing due to the growing world population and the dietary changes in countries with rapidly growing economies (Enghiad et al. 2017). In Syria, the production of bread wheat differs from year to year depending on climatic conditions and cultivated genotype (Wahid et al. 2007). Thus, development of high yielding wheat cultivars with better quality has always been a major objective of wheat breeding programs (Birhanu et al. 2016). However, success in wheat improvement in the long term generally depends on the magnitude of genetic variation and the extent to which the desirable characters are heritable (Naghavi and Marouf 2017).

Breeders usually cross elite wheat lines within a defined germplasm pool expecting to assemble better allele combinations in the progeny (Li et al. 2018). Intercrosses of existing elite wheat germplasm in each breeding cycle and selection has further narrowed the genetic diversity by the depletion of few alleles from a more diverse gene pool (Cox 1997). Importantly, monitoring genetic diversity levels within a breeding material is crucial for avoiding genetic erosion and for ensuring long-term selection potential (Fu 2015). Moreover, assessing and understanding the genetic structure of a crop population is an important first step towards linking genetics to phenotypic variation. The genetic structure of the T. aestivum cultivars grown in the Mediterranean basin including Syria varies largely and its is characterized by a high diversity, to modern varieties characterized by high yield potential, wide adaptation and technological quality (Mirali 2000; Shoiab and Arabi 2004). These differences could be caused by different breeding practices and requirements, one being that intensive selection pressure in wheat breeding began earlier in Northern and Western Europe (Orabi et al. 2014). Additionally, chromosomal differences can be caused by the introduction of certain germplasm in specific geographical regions (Purnhauser et al. 2010). However, genetic diversity in a modern agricultural setting can be estimated as a function of the range of wheat cultivars grown by farmers under geographical area at a given time (Matsuoka 2011).

The use of molecular markers for wheat genetic studies has recently received a great deal of attention from wheat breeders. However, the efficiency of polymorphism 
detection by amplified fragment length polymorphism (AFLP) in wheat is high compared with other available marker systems (Martos et al. 2005; Ejaz et al. 2015) since the AFLP technique combines the RFLP reliability with the power of PCR to amplify simultaneously many restriction fragments (Vos et al. 1995).

The aim of this work was to study the AFLP-genetic diversity within local and introduced cultivars of bread wheat grown in Syria which is typical of Mediterranean environments.

\section{Materials and Methods}

\section{Plant material}

Seeds from twenty-one wheat (Triticum aestivum L.) cultivars were selected to represent the germplasm grown in Syria. Seeds were provided by Syrian General Commission for Scientific Agricultural Research (SGCASR) at Douma, Syria and used in this study. They included five old local cultivars (Cham 2, Cham 6, Cham 8, Bouhouth 4 and Bouhouth 6) and 16 introduced cultivars (Table 1). Cham 2, 6 and 8 were developed in CIMMYT/ICARDA and released in 1984, 1991 and 1998, respectively. Bouhouth
4 and 6 were developed by SGCASR in 1987 and 1991, respectively. Twenty seeds from each cultivar were randomly selected and sown in a growth chamber at $22^{\circ} \mathrm{C}$ for 3 weeks and $1-2 \mathrm{~g}$ of fresh leaf material was harvested for DNA extraction.

\section{DNA extraction}

Genomic DNA was isolated from 15 individual plants of each cultivar according to the method of Doyle and Doyle (1990), with some modifications. DNA was quantified by spectrophotometer, by absorbance at $260 / 280 \mathrm{~nm}$. The DNA quality was then checked on $2 \%$ agarose gel.

\section{AFLP assays}

The AFLP procedure (Vos et al. 1995) as modified by Pillay and Myers (1999) was used to assess the genetic diversity. DNA was double digested with EcoRI and $M s e \mathrm{RI}$ at $37^{\circ} \mathrm{C}$ for $3 \mathrm{hrs}$. A small aliquot of the digested DNA was run on a $1.5 \%(\mathrm{w} / \mathrm{v})$ agarose gel to check if the DNA digestion was complete. The digested samples were incubated at $70{ }^{\circ} \mathrm{C}$ for $15 \mathrm{~min}$ to inactivate the restriction endonucleases. EcoRI and $M s e$ RI adapters were ligated to the digested DNA samples to generate template DNA for amplification. Pre-amplification was carried out with +1 -primers each

Table 1. Names and origins of 21 bread wheat cultivars used in this study.

\begin{tabular}{|c|c|c|c|}
\hline Species & Name & Code & Origin \\
\hline \multirow[t]{3}{*}{ Local cultivars } & Cham2 & Ch2 & Syria (CIMMYT/ICARDA)* \\
\hline & Cham6 & Ch6 & $"$ \\
\hline & Cham8 & Ch8 & $"$ \\
\hline \multirow[t]{18}{*}{ Introduced cultivars } & Bouhouth4 & Bou4 & Syria (Developed by SGCASR)** \\
\hline & Bouhouth6 & Bou6 & $"$ \\
\hline & ACSAD 885 & Ac885 & Syria (Developed by ACSAD)*** \\
\hline & ACSAD 59 & Ac59 & " \\
\hline & ACSAD 367 & Ac367 & $"$ \\
\hline & ACSAD 305 & Ac305 & $"$ \\
\hline & ACSAD 67 & Ac67 & $"$ \\
\hline & ACSAD 529 & Ac529 & $"$ \\
\hline & ACSAD 883 & Ac883 & $"$ \\
\hline & ACSAD 851 & Ac851 & $"$ \\
\hline & ACSAD 853 & Ac853 & $"$ \\
\hline & ACSAD 857 & Ac857 & $"$ \\
\hline & ACSAD 805 & Ac805 & $"$ \\
\hline & ACSAD 653 & Ac653 & $"$ \\
\hline & ICARDA MR17-41 & Ic41 & Syria (Developed by ICARDA)**** \\
\hline & ICARDA MR16-40 & Ic40 & $"$ \\
\hline & ICARDA MR19-43 & Ic43 & $"$ \\
\hline & ICARDA MR20-44 & IC44 & $"$ \\
\hline
\end{tabular}

*The International Maize and Wheat Improvement Center, **Syrian General Commission of the Agricultural Scientific Research, ***The Arab Center for the Studies of Arid Zones and Dry Lands, Syria, $* \star \star *$ The International Center for Agriculture Research in the Dry Areas 
Table 2. AFLP band numbers and polymorphic bands revealed by eight primer pairs in 21 wheat cultivars.

\begin{tabular}{llll}
\hline Primer pair & Total & $\begin{array}{l}\text { Polymorphic } \\
\text { bands }\end{array}$ & $\begin{array}{l}\text { \% of polymorphic } \\
\text { bands }\end{array}$ \\
\hline E-ACG X M-CAG & 40 & 25 & 62.5 \\
E-ACT X M-CAG & 30 & 21 & 70.0 \\
E-ACG X CAT & 42 & 33 & 78.6 \\
E-AAG X M-CTA & 45 & 27 & 60.0 \\
E-ACG X M-CAC & 43 & 25 & 58.1 \\
E-AGC X M-CTA & 41 & 17 & 41.5 \\
E-ACG X M-CTA & 33 & 15 & 45.5 \\
E-AGG X M-CAG & 33 & 14 & 42.4 \\
Mean & 38.38 & 22.13 & 57.3 \\
\hline
\end{tabular}

carrying one selective nucleotide $(E c o \mathrm{RI}+\mathrm{A}, M s e \mathrm{RI}+\mathrm{C})$ in a Gene Amp 9700 Thermocycler (Applied Biosystems, USA) for 20 cycles set at $94{ }^{\circ} \mathrm{C}$ denaturation $(30 \mathrm{sec})$, $56{ }^{\circ} \mathrm{C}$ annealing $(40 \mathrm{sec})$, and $72{ }^{\circ} \mathrm{C}$ extension $(50 \mathrm{sec})$. The initial denaturation was done at $94^{\circ} \mathrm{C}$ for $30 \mathrm{sec}$ and the final extension at $72^{\circ} \mathrm{C}$ for $8 \mathrm{~min}$. The amplification products were diluted 10 -fold in $\mathrm{H}_{2} \mathrm{O}$ and stored at $-20^{\circ} \mathrm{C}$. Selective AFLP amplification was carried out with EcoRI +3 and $M s e \mathrm{RI}+3$ primers and $5 \mu \mathrm{L}$ of the diluted PCR products from the pre-amplification.

Eight EcoRI, MseI primer pairs were screened on 21 wheat cultivars to assess the ability of these primer pairs to detect molecular variation (Table 2). The PCR amplifications were carried out as follows: one cycle at $94^{\circ} \mathrm{C}$ for $30 \mathrm{sec}, 68^{\circ} \mathrm{C}$ for $30 \mathrm{sec}$, and $72^{\circ} \mathrm{C}$ for $60 \mathrm{sec}$; followed by 12 cycles of touchdown PCR in which the annealing temperature was decreased by $0.7^{\circ} \mathrm{C}$ every cycle until a touchdown annealing temperature of $59^{\circ} \mathrm{C}$ was reached. Once reached, another 20 cycles were conducted as described above for pre-amplification. The reaction product $(8 \mu \mathrm{l})$ was mixed with $4 \mu \mathrm{l}$ of formamide loading buffer (98\% [v/v] formamide, $10 \mathrm{mM}$ EDTA, 0.005\% [v/v] of each of xylene cyanol and bromophenol blue) denatured by incubating at $90^{\circ} \mathrm{C}$ for $3 \mathrm{~min}$ and quickly cooled on ice. The products were analyzed on a $6 \%(\mathrm{w} / \mathrm{v})$ denaturing polyacrylamide gels. The gel was run at constant power (60 W) until the xylene cyanol was about two-thirds down the length of the gel. The experiments were repeated twice for each cultivar to confirm the repeatability and the monomorphic bands were removed from the analysis.

\section{Marker polymorphism}

Each silver stained AFLP gel was manually scored (1 for present, 0 for absent) and entered into a data matrix. The number of polymorphic and monomorphic bands was recorded for each primer combination; however, monomorphic bands were excluded from data analyses.
Percentage of polymorphism was calculated as the proportion of polymorphic bands over the total number of bands. Allelic polymorphic information content (PIC) was calculated using the following formula:

$$
\mathrm{PIC}=1-\Sigma\left(\mathrm{P}_{\mathrm{i}}\right)^{2}
$$

Where $\mathrm{Pi}$ is the proportion of the population carrying the $\mathrm{i}^{\text {th }}$ allele, calculated for each AFLP locus (Anderson et al. 1993).

\section{Genetic diversity estimation and cluster analysis}

The genetic dissimilarity $(D)$ matrix among cultivars was estimated according to Nei and Li (1979) coefficient. Principal coordinate analysis (PCA) based on genetic distance matrix was performed using the DCENTER and EIGEN algorithms of the NTSYS-pc software package (Rohlf 1992). Unweighted Pair-Group Method with Arithmetic Average (UPGMA), i.e. cluster analysis was used to assess pattern of diversity among wheat cultivars.

\section{Results and Discussion}

AFLP analysis generated a large number, of reproducible and unambiguous markers for fingerprinting T. aestivum cultivars used in the study. Initially DNA fingerprints were created using eight different AFLP primer combinations, from which three were selected for analysis. The primer pairs were sufficient to detect 177 polymorphic bands among the 21 cultivars resulting in an average of 22.13 (57.3\%) polymorphic loci per primer pair. Details of the bands scored with the different primer combinations are illustrated in Table 2. The PIC values in the present study ranged from 0.30 to 0.37 , with an average of 0.34 . Major allelic frequency ranged from 0.50 (Ic43) to 0.75 (Ch2 and Ch6) with a mean of 0.64 , and an estimated gene diversity of 0.45 (Table 3 ).

The pair-wise dissimilarity $(D)$ matrix is presented in Table 4. Mean value of $D$ was 0.54 , ranging from 0.32 to 0.66 . The highest $D(0.64)$ was obtained between cultivars Ic41 and Ac805, and between Ic66 and Ch6. The lowest $D$ was at AC885 and Bou6 with $D$ of 0.32 . This might be due to their common ecological and evolutionary story. Cluster analysis using the Nei's genetic distance algorithm separated the local from the introduced wheat cultivars into three clusters, with all local cultivars falling into one cluster, which can be further divided into three subgroups. Interestingly, all the local cultivars fall together under this cluster (Fig. 1). The PCA analysis with the entire AFLP data separated the local from the introduced wheat cultivars and formed distinct groups (Fig. 2). Knowledge about the genetic variation among bread wheat cultivars 
Table 3. Polymorphic information content (PIC), amplified alleles and gene diversity as revealed by AFLP.

\begin{tabular}{llll}
\hline Cultivar & Major Allele Frequency & Gene Diversity & PIC \\
\hline Ch2 & 0.7526 & 0.3724 & 0.3030 \\
Ch6 & 0.7526 & 0.3724 & 0.3030 \\
Ch8 & 0.6947 & 0.4242 & 0.3342 \\
Bou4 & 0.6474 & 0.4566 & 0.3523 \\
Bou6 & 0.6842 & 0.4321 & 0.3388 \\
Ac885 & 0.7105 & 0.4114 & 0.3267 \\
Ac59 & 0.5737 & 0.4891 & 0.3695 \\
Ac367 & 0.5579 & 0.4933 & 0.3716 \\
Ac305 & 0.6158 & 0.4732 & 0.3612 \\
Ac67 & 0.6579 & 0.4501 & 0.3488 \\
Ac529 & 0.7368 & 0.3878 & 0.3126 \\
Ac883 & 0.7105 & 0.4114 & 0.3267 \\
Ac851 & 0.6842 & 0.4321 & 0.3388 \\
Ac853 & 0.6421 & 0.4596 & 0.3540 \\
Ac857 & 0.6000 & 0.4800 & 0.3648 \\
Ac805 & 0.6789 & 0.4360 & 0.3409 \\
Ac653 & 0.5632 & 0.4920 & 0.3710 \\
Ic41 & 0.5474 & 0.4955 & 0.3727 \\
Ic40 & 0.5737 & 0.4891 & 0.3695 \\
Ic43 & 0.5579 & 0.4933 & 0.3716 \\
Ic44 & 0.5000 & 0.5000 & 0.3750 \\
Mean & 0.6401 & 0.4501 & 0.3480 \\
\hline & & &
\end{tabular}

is essential for the effective use of genetic resources in breeding programs ( $\mathrm{Li}$ et al. 2018). The primary aim of this study was to examine the genetic diversity within Syrian local and introduced bread wheat cultivars using AFLP markers to obtain useful molecular data regarding the local gene pool. Results showed a decrease in the genetic diversity over time in Syrian bread wheat cultivars, which might be due to the intensive use of a limited number of cultivars as progenitors in different Syrian breeding programs.

The low PIC and dissimilarity values found among the local and introduced cultivars in this study, might be attributed to the rigorous selection pressure aimed at cultivar purity and associated breeding practices. Such practices, which are aimed at genetic homogenization and purity of varieties, may result in an improvement in yield and other agronomically important traits at the expense of reduction in the genetic base of crops. A low values of PIC were also obtained in other earlier studies on wheat (Plaschke et al. 1995; El-Esawi et al. 2018). Our results can be supported also by Huang et al. (2002) who suggested also that genetic diversity in wheat is narrow due to a modern breeding.

In this work, AFLP fingerprinting for estimating the levels of genetic diversity in local and introduced bread

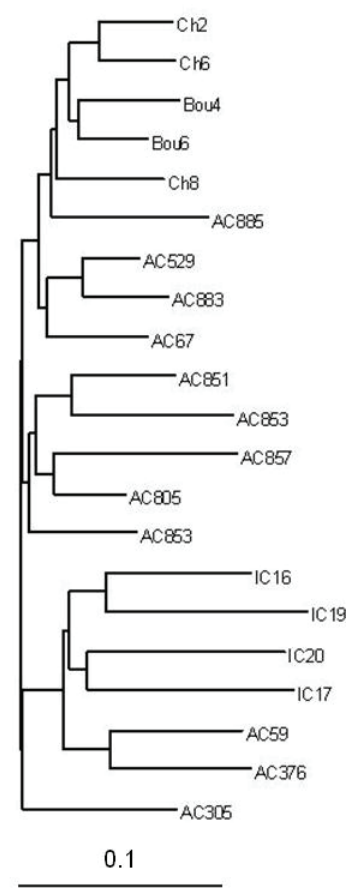

Figure 1. UPGMA dendrogram based on genetic similarities discriminated all the bread wheat cultivars used in this study.

wheat cultivars revealed an apparent narrow genetic variability (Tables 2,3 ). The estimated gene diversity was 0.45 , which was lower than the estimates of 0.66 in 43 bread wheat cultivars from 7 USA market classes (Chao et al. 2007) and 0.77 in 998 accessions from 68 countries (Huang et al. 2002). Earlier works reported that the higher gene diversity among bread wheat cultivars attributed to the use of genetic materials from well defined market classes or landraces, or genotypes from gene banks, or cultivars from various geographic locations (Plaschke et al. 1995; Roussel et al. 2004). However, it is widely believed that modern breeding practices have led to a noticeable decrease of genetic diversity in modern cultivars (Vellve 1993). This erosion in genetic variation might result in reduction of the plasticity of crops to respond to changes in weather, agricultural practices, disease populations, or modern requirements (Manifesto et al. 2001). The AFLP marker dendrogram showing genetic relationships from UPGMA cluster analysis revealed three major groups and subgroups and separated the local from the introduced wheat cultivars. Reasons for the presence of subgroups within larger can be attributed to differences in genetic pool, geographical origin, human or environmentally driven selection or genetic drift (Buckler and Thornsberry 2002). However, the Syrian local cultivars were mainly grown in a very local and restricted geographical area, making transport to distant zones from their local origin 
Table 4. Matrix of pair-wise genetic dissimilarity among Syrian bread wheat cultivars based on Nei and Li coefficients.

\begin{tabular}{|c|c|c|c|c|c|c|c|c|c|c|c|c|c|c|c|c|c|c|c|c|}
\hline & $\begin{array}{c}\text { Ch } \\
8 \\
\end{array}$ & $\begin{array}{c}\text { Ch } \\
2 \\
\end{array}$ & $\begin{array}{c}\text { Ch } \\
6 \\
\end{array}$ & $\begin{array}{c}\text { Bo } \\
4\end{array}$ & $\begin{array}{c}\text { Bo } \\
6 \\
\end{array}$ & $\begin{array}{c}\mathrm{AC} \\
885 \\
\end{array}$ & $\begin{array}{l}\text { AC } \\
59 \\
\end{array}$ & $\begin{array}{c}\text { AC } \\
367 \\
\end{array}$ & $\begin{array}{c}\mathrm{AC} \\
305 \\
\end{array}$ & $\begin{array}{l}\text { AC } \\
67 \\
\end{array}$ & $\begin{array}{c}\mathrm{AC} \\
529 \\
\end{array}$ & $\begin{array}{c}\mathrm{AC} \\
883 \\
\end{array}$ & $\begin{array}{c}\text { AC } \\
851 \\
\end{array}$ & $\begin{array}{c}\mathrm{AC} \\
853 \\
\end{array}$ & $\begin{array}{c}\text { AC } \\
857 \\
\end{array}$ & $\begin{array}{c}\mathrm{AC} \\
805 \\
\end{array}$ & $\begin{array}{c}\text { AC } \\
963 \\
\end{array}$ & $\begin{array}{l}\text { IC } \\
44 \\
\end{array}$ & $\begin{array}{l}\text { IC } \\
41 \\
\end{array}$ & $\begin{array}{l}\text { IC } \\
40 \\
\end{array}$ \\
\hline Ch 8 & 0.00 & & & & & & & & & & & & & & & & & & & \\
\hline Ch 2 & 0.44 & 0.00 & & & & & & & & & & & & & & & & & & \\
\hline Ch 6 & 0.44 & 0.37 & 0.00 & & & & & & & & & & & & & & & & & \\
\hline Bo 4 & 0.44 & 0.45 & 0.40 & 0.00 & & & & & & & & & & & & & & & & \\
\hline Bo 6 & 0.44 & 0.43 & 0.40 & 0.38 & 0.00 & & & & & & & & & & & & & & & \\
\hline AC 885 & 0.40 & 0.44 & 0.46 & 0.41 & 0.32 & 0.00 & & & & & & & & & & & & & & \\
\hline AC 59 & 0.55 & 0.55 & 0.59 & 0.57 & 0.50 & 0.47 & 0.00 & & & & & & & & & & & & & \\
\hline AC 367 & 0.56 & 0.57 & 0.62 & 0.59 & 0.53 & 0.52 & 0.42 & 0.00 & & & & & & & & & & & & \\
\hline AC 305 & 0.53 & 0.51 & 0.55 & 0.53 & 0.50 & 0.51 & 0.55 & 0.52 & 0.00 & & & & & & & & & & & \\
\hline AC 67 & 0.47 & 0.48 & 0.49 & 0.44 & 0.43 & 0.42 & 0.51 & 0.53 & 0.48 & 0.00 & & & & & & & & & & \\
\hline AC 529 & 0.46 & 0.45 & 0.44 & 0.48 & 0.41 & 0.40 & 0.53 & 0.54 & 0.46 & 0.40 & 0.00 & & & & & & & & & \\
\hline AC 883 & 0.44 & 0.51 & 0.45 & 0.48 & 0.46 & 0.42 & 0.58 & 0.60 & 0.50 & 0.45 & 0.35 & 0.00 & & & & & & & & \\
\hline AC 851 & 0.48 & 0.50 & 0.49 & 0.53 & 0.48 & 0.49 & 0.52 & 0.55 & 0.49 & 0.52 & 0.48 & 0.52 & 0.00 & & & & & & & \\
\hline AC 853 & 0.45 & 0.45 & 0.49 & 0.46 & 0.46 & 0.44 & 0.52 & 0.52 & 0.49 & 0.44 & 0.45 & 0.48 & 0.46 & 0.00 & & & & & & \\
\hline AC 857 & 0.53 & 0.54 & 0.56 & 0.55 & 0.53 & 0.53 & 0.58 & 0.58 & 0.54 & 0.51 & 0.54 & 0.57 & 0.52 & 0.47 & 0.00 & & & & & \\
\hline AC 805 & 0.47 & 0.48 & 0.49 & 0.49 & 0.45 & 0.42 & 0.53 & 0.55 & 0.51 & 0.46 & 0.43 & 0.46 & 0.44 & 0.39 & 0.43 & 0.00 & & & & \\
\hline AC 653 & 0.58 & 0.59 & 0.62 & 0.61 & 0.57 & 0.54 & 0.55 & 0.58 & 0.53 & 0.56 & 0.55 & 0.55 & 0.45 & 0.54 & 0.55 & 0.46 & 0.00 & & & \\
\hline IC 44 & 0.60 & 0.62 & 0.63 & 0.64 & 0.60 & 0.60 & 0.55 & 0.58 & 0.64 & 0.61 & 0.62 & 0.62 & 0.57 & 0.57 & 0.61 & 0.55 & 0.55 & 0.00 & & \\
\hline IC 41 & 0.58 & 0.60 & 0.58 & 0.59 & 0.58 & 0.57 & 0.59 & 0.58 & 0.65 & 0.61 & 0.61 & 0.62 & 0.61 & 0.58 & 0.64 & 0.60 & 0.67 & 0.58 & 0.00 & \\
\hline IC 40 & 0.57 & 0.59 & 0.59 & 0.58 & 0.55 & 0.56 & 0.58 & 0.57 & 0.58 & 0.55 & 0.55 & 0.59 & 0.58 & 0.54 & 0.59 & 0.56 & 0.61 & 0.60 & 0.56 & 0.00 \\
\hline IC 43 & 0.63 & 0.63 & 0.66 & 0.63 & 0.59 & 0.59 & 0.54 & 0.58 & 0.60 & 0.59 & 0.59 & 0.62 & 0.62 & 0.59 & 0.65 & 0.61 & 0.61 & 0.59 & 0.64 & 0.54 \\
\hline
\end{tabular}

difficult with the exception of population movements. Moreover, cultivars derived from CIMMYT germplasm have been continuously introduced into Syria from the 1970s, and CIMMYT/ICARDA have enormously promoted shuttle breeding and the intensive interchange of germplasm around the world. This could be the reason why introduced bread wheat cultivars presently has a

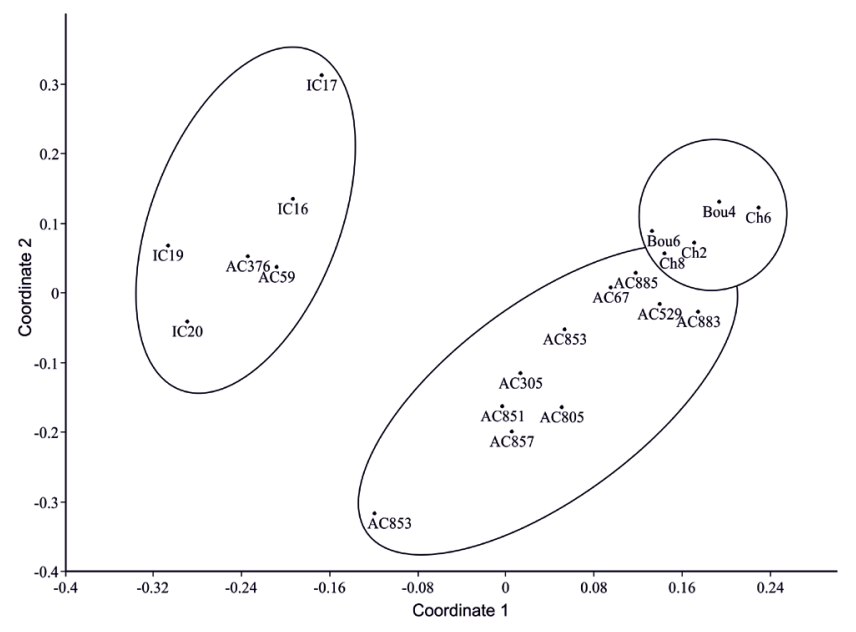

Figure 2. Principal coordinate map of the 21 bread wheat cultivars. common genetic background. On the other hand, this work revealed that AFLP is a very sensitive method for detecting markers in genetic studies of wheat crops. The banding patterns attained using AFLP were found to be highly reproducible when the same DNA sample was used in independent experiments (Pillay and Myers 1999). Silver staining was used in this study because silver-stained AFLP gels are thought to produce a larger number of better-defined bands than phosphorous-32-labeled gels (Chalhoulb et al. 1997).The AFLP analysis used in the present work demonstrate low PIC and dissimilarity values found among local and introduced bread wheat cultivars grown in Syria, which can be attributed to the rigorous selection pressure aimed at variety purity and associated breeding practices. This suggests the need of broadening the genetic base of Syrian wheat breeding materials, including local landraces.

\section{Acknowledgements}

The authors thank the Director General of AECS and the Head of the Biotechnology Department for their support this work, and thanks also extended to Dr. Orabi (Copenhagen University) for his critical readings of the manuscript. 


\section{References}

Anderson JA, Churchill JE, Autrique SD, Tanksley S, Sorrells ME (1993) Optimizing parental selection for genetic linkage maps. Genome 36:181-188.

Birhanu M, Sentayehu A, Alemayehu A, Ermias A, Dargicho D (2016) Genetic variability, heritability and genetic advance for yield and yield related traits in bread wheat (Triticum aestivum L.) genotypes. Glob J Sci Front Res 16:12-15.

Buckler ES, Thornsberry JM (2002) Plant molecular diversity and application to genomics. Curr Opin Plant Biol 5:107-111.

Chalhoulb BA, Thibault S, laucou V, Rameau C, Hofte H, Cousin R (1997) Silver staining and recovery of AFLP ${ }^{\mathrm{TM}}$ amplification products on large denaturing polyacrylamide gels. Biotech 22:216-220.

Chao S, Zhang W, Dubcovsky J, Sorrells M (2007) Evaluation of genetic diversity and genome-wide linkage disequilibrium among U.S. wheat (Triticum aestivum L.) germplasm representing different market classes. Crop Sci 47:1018-1030.

Cox T (1997) Deepening the wheat gene pool. J Crop Prod 1:145-168.

Doyle JJ, Doyle JL (1990) Isolation of plant DNA from fresh tissue. Focus 12:3-15.

El-Esawi M, Witczak J, Abomohra AE, Ali HM, Elshikh MS, Margaret AM (2018) Analysis of the genetic diversity and population structure of Austrian and Belgian wheat germplasm within a regional context based on DArT markers. Genes 9:47.

Ejaz M, Qidi Z, Gaisheng Z, Na N, Huiyan Z, Qunzhu W (2015) Analysis of genetic diversity identified by amplified fragment length polymorphism marker in hybrid wheat. Genet Mol Res 14:8935-8946.

Enghiad A, Danielle Ufer D, Countryman AM, Thilmany DD (2017) An overview of global wheat market fundamentals in an era of climate concerns. Int J Agron 17:1-15.

Fu YB (2015) Understanding crop genetic diversity under modern plant breeding. Theor Appl Genet 128:2131-2142.

Hung XQ, Borner A, Roder MS, Ganal MW (2002) Assessing genetic diversity of wheat (Triticum aestivum $\mathrm{L}$.) germplasm using microsatellite markers. Theor Appl Genet 105:699-707.

Li A, Liu D, Yang W, Kishii M, Mao L (2018) Synthetic hexaploid wheat: yesterday, today, and tomorrow. Engineering 4:552-558.

Manifesto MM, Schlatter AS, Hopp HE, Suarez EY, Dubcovky J (2001) Quantitative evaluation of genetic diversity germplasm using molecular markers. Crop Sci 41:682-690.

Matsuoka Y (2011) Evolution of polyploid Triticum wheats under cultivation: the role of domestication, natural hybridization and allopolyploid speciation in their diversification. Plant Cell Physiol 52:750-764.

Martos V, Royo C, Rharrabti Y, Garcia del Morala LF (2005) Using AFLPs to determine phylogenetic relationships and genetic erosion in durum wheat cultivars released in Italy and Spain throughout the 20th century. Field Crop Res 91:107-116.

Mirali N (2000) Heterogeneity within old and modern durum and bread wheat grown in Syria using the A-PAGE and SDS-PAGE electrophoretic techniques. Plant Var Seeds 13:149-157.

Naghavi MR, Marouf K(2017) Evaluation of genetic diversity and traits relations in wheat cultivars under drought stress using advanced statistical methods. Acta Agric Slov 109:403.

Nei M, Li WH (1979) Mathematical model for studying genetic variation in terms of restricting endonucleases. Proc Natl Acad Sci USA 76:5269-5273.

Orabi J, Jahoor A, Backes G (2014) Changes in allelic frequency over time in European bread wheat (Triticum aestivum L.) varieties revealed using DArT and SSR markers. Euphytica 197:447-462.

Plaschke J, Ganal MW, Roder MS (1995) Detection of genetic diversity in closely related bread wheat using microsatellite markers. Theor Appl Genet 91:1001-1007.

Pillay M, Myers GO (1999) Genetic diversity in cotton assessed by variation in ribosomal RNA genes and AFLP markers. Crop Sci 39:1881-1886.

Purnhauser L, Bóna L, Láng L (2010) Occurrence of 1BL.1RS wheat-rye chromosome translocation and of Sr36/Pm6 resistance gene cluster in wheat cultivars registered in Hungary. Euphytica 179:287-295.

Rohlf FJ (1992) NTSY-pc. Numerical taxonomy and multivariate analysis system. Exeter Software, Setauket, New York, USA.

Roussel V, Koenig J, Beckert M, Balfourier F (2004) Molecular diversity in French bread wheat accessions related to temporal trends and breeding programs. Theor Appl Genet 108:920-930.

Shoaib A, Arabi MIE (2004) Genetic diversity among Syrian cultivated and landraces wheat revealed by AFLP markers. Genet Res Crop Evol 53:901-906.

Vellve R (1993) The decline of diversity in European agriculture. Ecologist 23:64-69.

Vos P, Hogers R, Bleeker M, Reijans M, Lee T, Hornes M, Frijters A, Pot J, Peleman J, Kuiper M, Zabeau M (1995) AFLP: a new technique for DNA fingerprinting. Nucl Acids Res 23:4407-4414.

Wahid A, Gelani S, Ashraf M, Foolad MR (2007) Heat tolerance in plants: an overview. Environ Exp Bot 61:199-223. 